\title{
Perceived Environmental Uncertainty Along the Thai Rice Supply Chain: An Empirical Approach
}

\author{
Phatcharee Toghaw Thongrattana* \\ Sydney Business School, University of Wollongong, \\ 2522, NSW, Australia \\ E-mail: ptt175@uow.edu.au \\ Nelson Perera \\ Sydney Business School, University of Wollongong, \\ 2522, NSW, Australia
}

\begin{abstract}
Uncertainty generates unstable processes along supply chains, which in the end worsen their performance. Some sources of uncertainty in agri-food supply chains are distinct from those affecting general supply chains. These include issues such as variable harvest and production yields, and the huge impact of climate conditions. Thus, a deep understanding of which uncertainty factors mostly affect on agri-food supply chain management and its performance is vital for allow agribusiness to deal with them effectively. The purpose of this study is to discuss the perceived environmental uncertainties in the context of the rice supply chain in Thailand. A review of the literature indicates that perception of seven factors — supply, demand, process, planning and control, competitor behavior, government policy, and climate uncertainty- are all potential causes of uncertainty and hence instability in the Thai rice supply chain. The research method used in order to confirm these factors is a survey with mail-out questionnaires to rice millers and rice exporters in Thailand. Descriptive statistics are employed to review which uncertainty factors within the rice supply chain are perceived as the greatest. Major findings show that planning and control, competitor behavior, government policy and climate uncertainties are the most influential factors. Because they depend upon information availability, accuracy, and throughput times, planning and control remain highly uncertain because information technology is rarely used in the Thai rice industry. Thus, lack of appropriate IT tools means that environmental uncertainties cannot be dealt with effectively. In addition, there is high competition in both the domestic and international rice market, leading to highly unpredictable competitor behaviors. As is the case in many developing countries, Thai government policies are turbulent, and the new factor of climate uncertainty in agri-food supply chain management is becoming more and more important in the Thai rice industry.
\end{abstract}

Keywords: perceived environmental uncertainty, agri-food supply chain, and Thai rice supply chain

\section{Introduction}

There has been extensive study of strategic supply chain management in order to improve supply chain performance in the real world. This is because in the current climate, uncertainty in the business environment is a crucial factor on both the supply and the demand side, one which influences many companies across many industries to engage in an ongoing process of adaption of supply chain management. Improvements such as reducing inventory cost through 'controlling uncertainty' is one of the three steps, along with benchmarking current

\footnotetext{
${ }^{*}$ Corresponding Author
} 
performance and planning changes, to achieve supply chain performance improvement (Davis 1993). To properly control uncertainty along a supply chain, it is essential to identify which sources of uncertainty exist. Different industries can face different uncertainty factors.

Several researchers have noted that turbulence in business factors such as supply, demand, government policy, competitor behavior, etc. has existed in any supply chains (Davis 1993; Li 2002; Childerhouse and Towill 2004; van Donk and van der Vaart 2005; Hsiao 2006; Paulraj and Chen 2007), and these increase the level of risk involved in managing business (Boyle et al. 2008). However, some sources of uncertainty in the agri-food supply chains, such as variable harvest and production yields and the huge impact of climate conditions, are distinct from those in general supply chains (Wijnands and Ondersteijn 2006). Accordingly, due to the importance of environmental factors, the rice supply chain in Thailand has been chosen as a good example in order to investigate the perceived environmental uncertainty of agri-food supply chains.

Rice is a key agricultural product of Thailand and plays a vital role in the Thai economy with rice farms comprising more than $50 \%$ of farm land use in that country (Krasachat 2004). Moreover, Thailand is the main rice exporter in the world rice market (David 1992). Not only is the rice agribusiness vital for Thailand, but the literature also shows that the performance of the rice supply chain in Thailand can be impacted by uncertainty factors, and by interruptions in the rice supply chain. All these must be taken into consideration in order to improve the rice supply chain in Thailand.

\section{Thai Rice Supply Chain}

Among the many categories of agricultural crops in Thailand, rice is the most important in term of both employment and trade (Meenaphant 1981). Rice farms conmprise over $50 \%$ of farm land use in Thailand and rice farmers make up around $56 \%$ of the Thai population (Krasachat 2004). Thailand is the main rice exporter on the world rice market (David 1992). The types of rice in Thailand can be classified according to the hardness of the rice, the season of the rice harvest, features of the rice farm or the rice traded. For example, there are two types of rice according to season: 'rained'or 'major' rice (grown in the wet season during May-July, and harvested during NovemberDecember) and 'off-season' or 'minor' rice (grown during the dry season during December-January and harvested during May-June).

Figure 1 shows the supply chain of paddy rice from farmers to millers and from millers to customers. The largest quantity of paddy rice (wet season rice) is purchased almost immediately from farmers by millers or paddy merchants right after harvesting in January-April and this can lead to a large surplus of rice, while off-season rice which grows in irrigated area flows to rice mills during June-September of each year (Thai Rice Foundation under Royal Patronage 2006b; International Rice Research Institute 2007). After harvesting, the next important process is drying because it directly affects grain quality and poor drying can result in losses (Gummert and Rickman 2006). The paddy rice can be purchased directly from the farmers by rice millers, or indirectly from the farmers through the Thai government and its rice mortgage scheme. Some paddy rice from farmers

Figure 1. Rice and information flow (modified from Thai Rice Foundation under Royal Patronage 2006b)

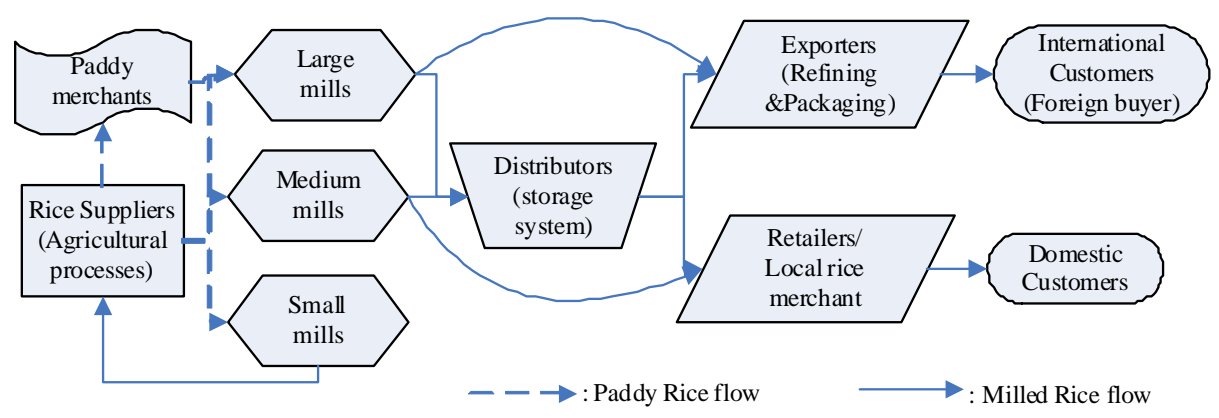


who grow the rice for their own consumption is milled by small or local rice mills (capacity of 1-12 tons $/ 24$ hour), while paddy rice from medium-large rice farms is milled by medium (capacity of 30-60 tons per 24 hours) and large mills (capacity of 100 tons per 24 hours), and is then refined and packed for domestic customers by retailers and for international customers directly by exporters. Milled rice is can also be transferred to rice distributors who manage storage systems before being distributed to retailers or exporters. The domestic demand is met by delivering milled rice through retailers to domestic customers. The international demand is fulfilled by passing rice through exporters who then sell to international customers (Thai Rice Foundation under Royal Patronage 2006b).

Thus, rice millers and rice exporters who are wholesalers in the rice supply chain and who deal with domestic and international demand respectively are the target sample of this study.

\subsection{Rice Supply Side}

As mentioned above, the major season of rice production in Thailand starts from May to July for tilling and planting, and from November to December for harvesting (International Rice Research Institute 2007). The precise timing of this, however, depends on the amount of rainfall and this can vary from year to year. (Thai Rice Foundation under Royal Patronage 2006a). The season for 'minor' rice production begins in December-January, and it is harvested from May to June in irrigated areas in central Thailand (International Rice Research Institute 2007). Though the timing of this kind of rice can vary too, it varies less than 'major' rice and, of course, the amount of water available, either through rain or irrigation, can create variations in the amount of rice production for both types of rice. The process of rice cropping has 5 steps: land preparation, crop establishment, harvesting, post harvesting (threshing, drying and cleaning) and storage (Thai Rice Foundation under Royal Patronage 2006a) but production size and hence supply chain uncertainty depends most on the amount of water available.

The rice production environment includes 'topography, soil type, water regime, and climate factors (David 1992), but rice can also be categorized into 4 types according to the water environment of the land in which it is grown: irrigated area, rain fed lowland, deepwater land, and upland or dry land (David 1992, p.9). In Thailand, in $199162 \%$ of rice came from rain fed land, $27 \%$ was irrigated, and only $8 \%$ was from deepwater land (IRRI 1991). In addition to tropical rainfall, temperature and solar radiation are also climate determinants in terms of the rice crop period, productivity and stability because they affect the growth and development of the rice plants (Yoshida 1981).

Rice yield, however, depends on both controllable and uncontrollable factors. The uncontrollable factors are climate conditions and soil fertility as discussed above, while the controllable factors include, for example, seed, fertilizer, insecticide, and irrigation and water management (Sriswasdilek 1990). Generally, rice yield can fluctuate depending on the varieties of rice, seasonality and the environment (Yoshida 1981), diseases, soil factors, physiological opportunities, and insects (David 1992, p.35). From 2003 to 2007, the amount of rice farming land in Thailand was stable at approximately 10 million hectares, leading to a production of rice of around 25-30 tons. Between 1990 and the present, under the Arkansas Global Rice Model (AGRM), the average percentage of annual rice production increased by $1.54 \%$ (FAPRI 2008). Rice yields (tons per hectare) fluctuated only slightly and increased only a small amount in Thailand. After 1980, however, compared to the rice yields in Vietnam, the Philippines, India and China, the rice yield of Thailand was very low (FAOSTAT Database 2008).

There are other factors which cause minor variations in production level. The rice yield in irrigated areas in Thailand is twice as much as in non-irrigated area (IRRI 1991). In addition, the rice yield of smaller farms (0.1-0.99 ha) is often higher than the rice yield of larger farms (Matsuda 1990). As nowadays farmers tend to utilize fertilizer, weed killers and other chemicals as well as planting more modern varieties of rice, crop disease, insects and weeds cause less variation in rice yield. Instead, temperature and water have become the primary supply factors influencing rice yield in South-East Asia (Herdt 1992, p.48).

\subsection{Rice Demand Side}

Domestic demand for rice is stable at nearly 10 million tons per year with an average increase of $0.55 \%$ every year (FAPRI 2008) because rice is the staple food in Thailand and the population is increasing very slightly. Since Thailand is the main rice exporter to 
the world market, reaching around 10 million tons in 2008 and having targeted 8.5 million tons in 2009 (Office of Agricultural Economics 2009), around 50 $\%$ of all demand for Thai rice relies on the international demand.

Because customer demand for rice on the global market depends on factors such as world population and eating behavior, the trend has increased slightly by approximately 3\% (historical data from 1961 to 2003). On the other hand, rice consumption per capita is estimated to have declined by $4 \%$ in 2010 because of changes in diet in countries such as Japan, Taiwan and China (Calpe 2004). According to the AGRM, between 1997 and 2007 world rice consumption was 380-420 million tons, and between 2008 and 2017, world rice consumption is forecast to reach 460 million tons, with an average increase rice consumption of $1.04 \%$ (FAPRI 2008).

Although the volume of Thai rice which is exported is expected to continue to grow between 1997 and 2017 because the quality of Thai rice is high and its Jasmine rice is unique, the historical data from 2002 to 2008 shows that the volume of Thai rice exports has fluctuated up and down. While, on the one hand, the demand for rice on the world market tends to grow and natural disasters have at times lowered rice production in other rice exporting countries such as Vietnam and the Philippines, on the other hand, when conditions are good for rice production in these competitor countries, their price is lower than the Thai price, so the demand for this is lower.

\section{Perceived Environmental Uncertainty and Supply Chain Management (SCM)}

Uncertainty refers to the unpredictability of environmental or organizational variables that have an impact on corporate performance' (Miller 1993, p.694). Notably, the definition of environmental uncertainty in organization theory as summarized by Milliken (1987, p.134) is: 'an inability to assign probability as to the likelihood of future events, a lack of information about cause-effect relationship, and an inability to predict accurately what the outcomes of a decision might be' (Duncan 1972, p.318). In other words, environmental uncertainty is 'an individual's perceived inability to predict something accurately' (Milliken 1987, p.136). From the perspective of an organization, the components of the external environment are: customers, suppliers, competitors, socio-politics and technology, while the internal environment consists of organizational personnel, functions and levels (Duncan 1972).

As a supply chain is a network of enterprises, individuals, facilities and information or materialhandling systems that connect our supplier's supplier to our customer's customer (Frazelle 2002), according to Duncan (1972) the above environments are also relevant to the members in a supply chain. Customers and suppliers, which are viewed as external factors of organisations can be viewed as internal factors of a supply chain.

Supply chain uncertainty is one of the three factors - the other two are location and manufacturing practices - which affect supply chain performance in terms of lead time, inventory level, time to market, quality, customer service and flexibility (Bhatnagar and Sohal 2005). From the point of view of the supply chain, environmental uncertainty is the external factor which is a driving force for supply chain management $(\mathrm{Li}$ 2002). Environmental uncertainty (suppliers, manufacturing, and customers) plagues supply chain performance (Davis 1993; Bhatnagar and Sohal 2005). Similarly, Childerhouse and Towill (2004) proposed a circular uncertainty concept divided into 4 components: demand, supply, control and process. Wilding (1998), instead, considers dynamic behavior experienced by supply chains as being caused by deterministic chaos, parallel interactions and demand amplification. From a managerial perspective, environmental uncertainty can lead supply chain managers to perceive decision-making uncertainty in term of unpredictable decision outcomes related to lack of information, knowledge, and ability (Duncan 1972), and this uncertainty can have a negative impact on both financial and non-financial performance along the supply chain (Hsiao 2006).

Agri-food supply chains are uniquely susceptible to variations in natural conditions. As Wijnands and Ondersteijn (2006) state, the unique characteristics of agri-food supply chains are 'the biological agricultural production relating to nature, weather and uncontrollablenatural forces, perishability of products and environmental concerns' (Wijnands and Ondersteijn 2006, p.8). van der Vorst and Beulens (2002, p.415) also note that 'perishability of products, variable harvest and production yields and the huge impact of 
weather conditions on customer demand' can all be sources of uncertainty in food supply chains. In addition to factors unique to food supply chains, there are also the four sources of uncertainty common to all supply chains: supply, demand and distribution, process, and planning and control, all of which fluctuate with respect to quantity, quality and time (van der Vorst 2000).

The linkages between climate and agricultural resources are significant shifts of traditional patterns of weather and climate, such as shift from drought to flood, or other extreme climate events (Ogallo et al. 2000). The impact of climate change on agricultural production in both history and prediction has been widely examined in world agriculture (Darwin et al. 1995; IPCC 2001). Another source of uncertainty is government policy which forces firms to react to its perceived or expected impacts. Especially in developing countries, government policies are unpredictable and turbulent (Badri et al. 2000).

It is obvious, therefore, that uncertainty factors are critical internal and external environments which drive firms to implement effective agri-food supply chain practices in order to maintain or improve supply chain performance. In addition to the above-mentioned five sources of uncertainty (Badri et al. 2000; van der Vorst 2000; Li 2002; Paulraj and Chen 2007), this study will examine two additional important uncertainty factors: government policy uncertainty and climate uncertainty, both of which are particularly important to the Thai rice supply chain.

\subsection{Demand Uncertainty}

Demand uncertainty in a supply chain refers to the uncertainty of customer requirements as to quantity, product types and time (Childerhouse and Towill 2004). In other words, demand uncertainty is the combination of unpredictability of general demand together with uncertainty of demand for specific varieties of the product (van der Vorst 2000). Characteristics of customer demand in regard to volume, variety and variability can also increase risk in a supply chain, and force supply chain members to practise integration of shared resources among partners (van Donk and van der Vaart 2005).

Today, the information revolution has improved the ability of customers to access a wide range of products and pricing information and this means that due to this higher level of product and price knowledge, customer demand can change quickly (Bolton and Dwyer 2003; Fawcett 2007). These unpredictable customer demands put stress on the scheduler decision-making process and cause volatility in production planning (Childerhouse et al. 2008). Even when the end customer demand may be relatively stable, variations in the perception of this demand all along the supply chain (from retailers to manufacturers to suppliers) can cause exaggerations in demand variations. This is known as the 'bullwhip effect' (Fawcett 2007, p.10).

In an agri-food supply chain, both the bullwhip effect and the real variability of consumer demand are clearly important since the supplier must not be out of stock when a customer wants to buy products (Taylor and Fearne 2006; Fawcett 2007). In the Thai rice supply chain, domestic demand is quite stable while international demand fluctuates, as mentioned above. Thus, demand uncertainty is an important factor in the Thai rice supply chain.

\subsection{Supply Uncertainty}

Supply uncertainty is uncertainty related to the delivery of product in time, in the right amount, or according to the right specifications (quality or price) (van der Vorst 2000). Supply uncertainty can be caused by the supplier and is primarily related to uncertainty of quantity, quality or the lead time of raw material to be delivered to manufacturers (Davis 1993; Childerhouse and Towill 2004). Because the supply side of agri-food supply chains are the biological agricultural production which depends to some extent on uncontrollable natural forces and environmental concerns (Wijnands and Ondersteijn 2006), and this complicates the management of inventory planning and control because of perishability and long production time (Hsiao et al. 2006), supply will fluctuate significantly. There are many additional factors, such as the government policy of reducing rice production (Yao 1997), which can cause rice output to vary in Thailand. Thus the supply side of the rice supply chain can also vary in terms of quantity, quality and lead time.

On the international rice market, the supply side is extremely concentrated with the top ten exporting countries supplying more than $90 \%$ of the total 
(Calpe 2004) and Thailand is the main rice exporter on the world rice market (Office of Agricultural Economics 2007). Consequently, the level of supply uncertainty in the Thai rice supply chain plays a vital role in the world rice market.

\subsection{Process Uncertainty}

Process uncertainty is related to production system uncertainty in regard to the availability of adequate capacity to produce a particular product (van der Vorst 2000). Process uncertainty can lead to uncertain order cycle times which are inadequate to meet customer time requirements (Childerhouse and Towill 2004). Such uncertainty may be due, for instance, to variations in the throughput time, in the quality of the product after processing or in the processing yield (van der Vorst 2000). Process uncertainty can be caused by low performance or by the nature of material flow and this can lead to uncertainty in the processing of the final product and then to uncertainty in shipment to customers (Davis 1993).

Each member of the supply chain must deal with differing processes. Rice millers must deal with the milling process, the storing and quality control as well as the packing process, while rice exporters must deal with storing and quality control and their own packing process. These processes can vary in terms of quantity, post-processing quality and though time (van der Vorst 2000).

\subsection{Planning and Control Uncertainty}

Planning and control uncertainty is related to the planning and communication structure needed to provide correct and on-time information about such issues as inventory level, production capacity and customer orders (van der Vorst 2000). Poor control systems, such as wrong decision rules or incomplete information, introduce uncertainty into the supply chain (Childerhouse and Towill 2004). Inaccurate forecasting of customers demand also allows supply chain members to face volatile situations which can impact on customer deliveries (Davis 1993). Of operational control, management control and strategic planning, it is operational control which is most intensively concerned with information management. Information is crucial to operational control for planning and control because the higher the quality of information input, the higher the quality of managerial decision making (Gorry and Morton 1989). Thus, as van der Vorst (2000) concludes, uncertainty in planning and control occurs when there is instability in availability, accuracy and throughput time of information related to operational control in a food supply chain. Nonetheless, the usage of information technology and information processing capability can deal effectively with uncertainty in the environment, the partnership and the task (Bensaou 1997) and this can reduce information uncertainty as well as uncertainty of planning and control along a supply chain. For this reason, the use of IT tools by supply chain members will also be examined.

\subsection{Competitor behavior Uncertainty}

Competitor behavior uncertainty refers to the unpredictability of competitor actions such as reducing the price of products ( $\mathrm{Li} 2002)$. In any organisation, the competitor is one external factor which can introduce perceived environment uncertainty into organisations (Duncan 1972). Competitor analysis is the one analytical technique for sustainable competitive strategy because competitor reactions and strategies have the potential to create industry-wide changes and broader environmental shifts (Porter 1980).

A competitor focus is the one component of market orientation that can improve market share performance when competitive structure is intense and customers are powerful (Heiens 2000). In market orientation, any actions from competitors that are attractive to customers should be reviewed (Slater and Narver 1994; Han et al. 1998). In addition, competitor behavior may not be stable. Intensive competition in either domestic or international markets and rapid change in technology can force competitors to take unpredictable action in order to gain a higher market share (Mentzer et al. 2000), and such action on the part of competitors can have both direct and indirect effects on the business performance of firms along the entire supply chain (Min and Mentzer 2000). Thus, competitor behavior is considered an important uncertainty factor in the supply chain.

The international rice market is unstable because of factors such as unstable weather in world riceproduction countries, market thinness and fragmentation, and rice-petroleum market linkages (Jayne 1993). Moreover, most rice-production countries introduce significant barriers such as import 
protection, domestic support and export promotion policies to international rice trade (Jayne 1993; Nielsen 2002). These situations have forced rice producers and rice exporters to introduce unique products such as low price and low quality rice from Vietnam (Nielsen 2002). Because the level of competition is relevant to uncertainty as to the predictability of competitor behavior, this is another factor which will be examined.

\subsection{Government Policy Uncertainty}

Laws, regulations, administrative procedures and policies formally sanctioned by the government and which impact on a firm's profitability by altering its costs or revenues, introduce government policy uncertainty into the supply chain (Badri et al. 2000).

Government regulation can provide both risks and benefits to business in many ways but unpredictable government policy can forces business decision-makers to take risks in investment, especially in new technology (Marcus 1981). For example, the changes in government policy in the Philippine agriindustry led to uncertain copra production. And this hurt the economic performance of the copra market (Mendoza and Farris 1992). Higher levels of unpredictable government policy forces firms to adopt strategies to survive in this situation (Badri et al. 2000).

Likewise, government policy has played an important role in Thai agricultural production because agricultural products are crucial in Thailand. The main reason is that almost $80 \%$ of Thais are involved in agricultural activities in rural areas (IRRI 2002). GDP in the agricultural section accounts for over $11 \%$ of Thai GDP. In addition, rice was among the top five products exported from Thailand to the world market in 2008 (World Bank 2009). Undoubtedly, the government intervenes in the rice industry in many ways: production, trade and export. The failure of a rice crop has led to starvation and political instability (Nielsen 2002).

In the Thai rice industry, the government has intervened in rice production and rice trading with an export rice tax (Roumasset and Setboonsarng 1988) and by mandating a reduction in rice capacity (Yao 1999), but these measures did not benefit farmers in the ways that the government expected (Yao 1997; 1999). In addition, during the rice season of $2009 / 2010$, the Thai National Rice Policy Committee replaced the current paddy mortgage scheme (The Thai National Rice Policy Committee 2009) by approving a new rice policy program to guarantee the rice price. Indeed, government policies of developing countries are turbulent and unpredictable (Badri et al. 2000), and affect the rice industry. In 2009, the competitiveness of Thai rice was predicted to be eroded because of the impact of the government intervention program aimed at keeping the domestic price high (FAO 2009b; a). A drop of $17 \%$ in Thai rice export was predicted compared to 2008 (FAO 2009a).

Therefore, perception of government policy has a significant effect on the stability of the Thai rice supply chain.

\subsection{Climate Uncertainty}

Climate uncertainty refers to the unpredictability of serious weather events in Thailand such as drought, flooding and temperature, events which can lead to decreased rice yield, rice supply shock, delay time of paddy rice to market or transportation disruption (Cruz et al. 2007). Of course, climate is a vital factor directly and indirectly affecting most agricultural and socio-economic systems associated with landuse planning, level of agricultural yield, consistency in yield, agricultural infrastructure, etc. especially in developing countries where the agricultural system is mostly dependent on rainfall and there is a lack of technological adaptations (Darwin et al. 1995; Ogallo et al. 2000).

Over the last 30 years, Bangkok, Hat Yai and Chiangmai, the large cities of Thailand, have experienced a number of flood-related disasters which have affected many people, farmers and the productivity of agriculture in the flood areas (The Office of Natural Resources and Environmental Policy and Planning 2008). There is evidence that in Thailand, drought and/or flood does considerable damage to cultivated rice areas. In 1919, for example, drought caused the crop failure in $43.4 \%$ of the cultivated rice area, and in 1942, flood caused crop failure in $34.3 \%$ of the cultivated rice area (Yoshida 1981). In 2040 the effects of climate change will reduce the rice yield by $20 \%$ in provinces such as the Thung Kula field, Chiang Rai, etc. (Sukin 2004). Although rice yield in Thailand could be increased by a two-fold increase in $\mathrm{CO}_{2}$ levels (Matthews and Wassmann 2003), the increase in rice production yield would be small. Studies strongly support the 
significance of climate factors affecting rice production in Thailand. Thus, climate uncertainty is considered as one of the uncertainty factors in the rice supply chain in Thailand.

In sum, a review of the literature indicates that there are seven uncertainty factors (supply, demand, process, planning and control, competitor behavior, government policy and climate) influencing the Thai rice supply chain.

\section{Research Question}

Though there have been a number of studies on the internal and external factors influencing supply chain performance, the uncertainty factors within a particular agri-food supply chain, such as the Thai rice supply chain, have not yet been investigated. The environmental uncertainties in the Thai rice supply chain have some similarities with other supply chains but in some ways are unique.

As the gaps in knowledge about uncertainty factors in the Thai rice supply chain were analysed, a critical research question arose: 'To what extent does perception of the uncertainty factors involved affect the rice supply chain in Thailand?' Answers to this research question are needed in order to provide additional and better understanding about the linkage between the uncertainty factors and rice supply chain partners in Thailand, as illustrated in Figure 1. Rice millers and rice exporters, known as rice supply chain members for the international market, will be investigated in order to answer the research question of this study.

\section{Methodology}

\subsection{Data Collection and Sample}

A questionnaire was mailed to 698 rice mill companies and 177 rice exporters all around Thailand. 46 questionnaires were returned from rice millers, and 36 from rice exporters due to, for instance, incomplete address, or business failure. From rice millers, 112 questionnaires were returned, but 14 of them were abandoned due to incomplete information, resulting in an effective response rate of $15.26 \%$. Meanwhile, from rice exporters, 29 questionnaires were received, but 7 of them were discarded due to incomplete information, resulting in an effective response rate of $16.42 \%$. These response rates are generally considered acceptable for surveys in developing countries (Ahmed et al. 2002). The final sample of rice millers included 8.16 , 19.59 , and $92.24 \%$ of small, medium, and large milling capacity, respectively. $16.33 \%$ are both rice millers and rice exporters, and $83.67 \%$ are only rice millers. In addition, $62.24 \%$ have joined the paddy rice mortgage scheme of the government over the last 5 years. The average amount of paddy rice milled is 22,525 tonnes per year, and the average inventory of paddy rice is 8,540 tonnes per year for each rice miller. The average amount of paddy rice milled is 22,525 tonnes per year, and the average inventory of paddy rice is 8,540 tonnes per year for each rice miller. The main international customers for international rice exporters are Hong Kong, China, Germany, USA, Belgium and the UAE. They export an average of 8,300 tons of milled rice, and the average inventory of milled rice is 1,300 tonnes per year for each rice exporter. $61-64 \%$ of the final sample (both rice millers and rice exporters) have implemented partially integrated supply chains, whilst $27-29 \%$ of them have implemented fully integrated supply chains.

\subsection{Instrument Development}

To measure seven environmental uncertainties within the Thai rice supply chain, this research developed and tested a measure of perceived environmental uncertainty from previous studies supply chain studies (Javidan 1984; Li 2002; Paulraj and Chen 2007), certain particular food supply chain studies (van der Vorst and Beulens 2002), rice industry studies (Bran and Bos 2005), specific developing country studies (Badri et al. 2000) summarized in section 5.2.1 and Table A1 in Appendix A. A pilot study was done and this measure was found to be valid and reliable. According to all statistical analysis in perceived environmental uncertainty measurement in the study of Lewis \& Harvey (2001), the Mann-Whitney non parametric statistics was applied because the data is qualitative data as a 7-Likert scale (Sheskin 1997). 


\subsubsection{Scale development}

There are three perspectives of the organizational environment : (i) objects, (ii) attributes, and (iii) perceptions (Duncan 1972; Bourgeois 1980). To measure uncertainty factors in an organization, the perception of these is what will be considered in this study because managers make their decisions based on these rather than on the objective uncertainty factors (Duncan 1972; Bourgeois 1980). In addition, two attributes of uncertainty factors are (i) the degree of change or unpredictability and (ii) the complexity or diversity of environmental factors (Duncan 1972; Downey et al. 1975). This study will focus on the unpredictability of factor because the degree of unpredictability of the factors has a greater effect on the variability of perceived uncertainty than does their complexity (Dill 1958; Duncan 1972). Moreover, unpredictability factors create more risk and difficulty for managers' decision-making and influences their effective strategy making (Bourgeois 1978). A summary of the characteristics of measured uncertainty factors in this study is shown in Table 1.

There are three aspects to supply, demand, process and planning, and control uncertainty: quality, quantity and time, and these are defined in Table 2. Competitor behavior uncertainty was measured under three aspects: their actions, competition in domestic and in international markets, a minor modification of Li's 2002 study. The measurement of government policy uncertainty had four aspects: policy affecting rice production, trading, paddy rice mortgage scheme, and any new government regulations (Javidan 1984; Badri et al. 2000; Bran and Bos 2005). Finally, climate uncertainty related to rice production is monitored in three aspects: drought, flooding (both in terms of occurrences and duration), and warmer temperatures (Cruz et al. 2007).

A 7-point Likert scale with end points of 'strongly disagree' and 'strongly agree' was applied to measure variables. Prior to data collection, pilot testing made

Table 1. The summary of the characteristics of measured uncertainty factors

\begin{tabular}{|l|l|}
\hline $\begin{array}{l}\text { Characteristics of } \\
\text { uncertain factors }\end{array}$ & Measurement in this study \\
\hline $\begin{array}{l}\text { Perspectives } \\
\text { Attitude }\end{array}$ & $\begin{array}{l}\text { Perception } \\
\text { Degree of change or unpredictability }\end{array}$ \\
\hline
\end{tabular}

the questionnaire easy to complete, comprehensible, and unambiguous for the respondents' range of knowledge and responsibility (Flynn et al. 1990). The feedback from the pilot study 'ensures the validity and reliability of measures' (Flynn et al. 1990, p.262). As the questionnaire was translated from English into Thai by professional translators, and some of rice millers are uneducated, a pilot study with a small number of samples (12 samples) was conducted. The objective of the pilot study was to improve the clarity and comprehensiveness of each question in the questionnaire. The face-to-face survey with the first draft of the questionnaire took no longer than 20

Table 2. Typology of sources of rice supply chain uncertainty and the aspects they concern (adapted from van der Vorst 2000, p.76)

\begin{tabular}{|c|c|c|c|}
\hline & Quantity aspects & Quality aspects & $\begin{array}{c}\text { Time } \\
\text { aspects }\end{array}$ \\
\hline Supply & $\begin{array}{l}\text { Inbound (paddy } \\
\text { or milled) rice } \\
\text { quantities }\end{array}$ & $\begin{array}{l}\text { Inbound (paddy } \\
\text { or milled) rice } \\
\text { quality }\end{array}$ & $\begin{array}{l}\text { Inbound (paddy } \\
\text { or milled) rice } \\
\text { timing to millers }\end{array}$ \\
\hline Demand & $\begin{array}{l}\text { Customer } \\
\text { demand of } \\
\text { outbound rice } \\
\text { quantities }\end{array}$ & $\begin{array}{l}\text { Customer } \\
\text { demand of } \\
\text { outbound rice } \\
\text { specifications }\end{array}$ & $\begin{array}{l}\text { Timing of } \\
\text { customer order }\end{array}$ \\
\hline Process & $\begin{array}{l}\text { Mill yield, } \\
\text { packing yield }\end{array}$ & $\begin{array}{l}\text { Milled rice } \\
\text { quality, Milled } \\
\text { rice quality after } \\
\text { storage }\end{array}$ & $\begin{array}{l}\text { Process } \\
\text { throughput times }\end{array}$ \\
\hline $\begin{array}{l}\text { Planning and } \\
\text { control }\end{array}$ & $\begin{array}{l}\text { Information } \\
\text { availability }\end{array}$ & $\begin{array}{l}\text { Information } \\
\text { accuracy }\end{array}$ & $\begin{array}{l}\text { Information } \\
\text { throughput times }\end{array}$ \\
\hline
\end{tabular}

minutes to acquire feedback from participants in order to improve clarity, understanding and adjust the length of the question. Thus, after this pilot study and based on feedback received from the participants, the final draft of the Thai version of the questionnaire was constructed. A copy of the final Thai version questionnaire was subsequently mailed to around 698 rice mill enterprises from the members list of the Thai Rice Mill Association, and 177 rice export companies from the member list of the Thai Rice Exporters Association.

\subsubsection{The scale reliability}

Reliability is 'the consistency of a measure of a concept' (Bryman 2003, p.71). Cronbach's alpha is the common technique to measure internal reliability for a set of two 
or more construct indicators, or multiple-item measures (Hair et al. 1995; Bryman 2003). The value of Cronbach's alpha should be high (Flynn et al. 1990). For an exploratory work in this study, Cronbach's alpha was accepted at above 0.6 (Nunnally 1967). In SPSS output to test scale reliability of each construct, the values of Corrected Item-total Correlation are the correlations between each item and the total scores of the construct in the questionnaire (Field 2009). These values are linked to the values of Cronbach's alpha. Any particular items where the value of Corrected Item-total Correlation is less than 0.3 are encouraged to be deleted in order to increase the value of Cronbach's alpha, and also to purify items in each construct (Field 2005). The reliability result of the scale is presented in Table 3.

The Cronbach's alpha of these scales was found to range from 0.622 to 0.934 when PU2 (The amount of rice product is enough for distribution as required) and PCU4 (Information concerning changes of customer orders cannot be distributed on time) were deleted. Careful examination of the deleted items revealed that PU2 is not relevant only to process uncertainty because whether the sufficient amount of rice product is ready for distribution as required or not, depends on factors including supply uncertainty, not only process uncertainty. Since PCU4 is measured on information concerning changes of customer orders while PCU1, 2 and 3 focus on information about stock level, PCU4 is less correlated with the total scores of the construct. Thus, it was decided to delete PU2 and PCU4 from further analysis.

\subsubsection{The scale validity}

Validity is the ability of a construct's indicator to measure accurately the concept under study (Hair et al. 1995). In the development of this instrument, the content validity as a judgment not open to numerical evaluation, was examined by providing measurement items from the comprehensive literature review and the pilot study before data collection (Flynn et al. 1990). Construct validity was measured by explanatory factor analysis (EFA) that \pm 0.3 cut-off factor loading as minimum level of measurement items was eliminated (Hair et al. 1995). EFA was conducted using principal component as method of extraction and varimax as the method of rotation, and the factor results are shown in Table 4. The Kaiser-Meyer-Olkin Measure $(\mathrm{KMO})$ is considered acceptable at 0.672 [greater
Table 3. Reliability of measurement scale

\begin{tabular}{|l|c|c|c|}
\hline Construct & $\begin{array}{c}\text { Cronbach's alpha } \\
\text { when particular } \\
\text { items deleted }^{1}\end{array}$ & $\begin{array}{c}\text { Number of } \\
\text { retained } \\
\text { items }\end{array}$ & $\begin{array}{c}\text { Particular items } \\
\text { deleted }^{2}\end{array}$ \\
\hline Supply & 0.718 & 4 & None \\
Demand & 0.714 & 4 & None \\
Process & 0.630 & 3 & PU2 \\
$\begin{array}{l}\text { Planning } \\
\text { and Control }\end{array}$ & 0.622 & 3 & PCU4 \\
Competitor & 0.613 & 4 & None \\
Government & 0.851 & 4 & None \\
policy & & 5 & None \\
Climate & 0.934 & & \\
\hline
\end{tabular}

items are deleted when their Corrected Item-total Correlation is less than 0.3

${ }^{2}$ referring to code of items in Table A1

than 0.5 is considered acceptable (Kaiser 1974)], and Bartlett's Test is highly significant at $\mathrm{p}<0.001$. Therefore, the factor analysis is appropriate to proceed.

As factor analysis is an exploratory study, it is to identify how many factors that should be extracted, the Kaiser-Guttman criteria (Eigenvalues greater than 1.0) together with scree plot (indicating the point of inflexion on the curve) (Cramer 2003; Field 2005). Thus, six factors are extracted as shown in Table 6. Careful analysis of factor loading ( above 0.3 ) shows that Factors 1, 4 and 6 are clearly represented by five climate uncertainty items, three process uncertainty items, and three planning and control uncertainty items, respectively. There are two areas of particular interest in the other factors. Firstly, the one item (SU2) of supply uncertainty appears to load on Factor 1 (grouped with climate uncertainty), and Factor 3 (grouped with demand uncertainty), whilst the other items load on Factor 5. Although unsurprisingly this may indicate that the item 'the properties of rice from rice producer can vary greatly within the same batch' might be correlated with climate uncertainty, it was decided to drop SU2 for late analysis because its factor loading is greater than 0.4 on more than one factor in order to remain appropriate internal consistency reliability of the instrument. Thus, Factor 3 is represented by four demand uncertainty items. Secondly, the items of competitor behavior 
uncertainty and government policy uncertainty are loaded on Factor 2. This indicates that the apparent characteristics between competitor behavior uncertainty and government policy uncertainty become less distinct in environmental uncertainty of the Thai rice supply chain.

\subsubsection{Independent Sample Non-parametric Test for analysis of the supply chain}

The perceived environmental uncertainty instrument was administered to two groups of Thai rice supply chain members: rice millers $(\mathrm{N}=98)$ and rice exporters $(\mathrm{N}=22)$. In order to determine if the environmental uncertainties from different rice supply chain members were perceived differently, the two results were compared using the MannWhitney non-parametric test for comparing two independent samples. The non-parametric test was applied because it is known as assumption-free in

Table 4. Results of rotated factor pattern for retained items of uncertainty factors in the rice supply chain.

\begin{tabular}{|c|c|c|c|c|c|c|}
\hline \multirow{2}{*}{ Item } & \multicolumn{6}{|c|}{ Factors } \\
\hline & 1 & 2 & 3 & 4 & 5 & 6 \\
\hline $\begin{array}{l}\text { SU1 } \\
\text { SU2 } \\
\text { SU3 } \\
\text { SU4 }\end{array}$ & .47 & & .54 & & $\begin{array}{l}.67 \\
.63 \\
.41\end{array}$ & \\
\hline $\begin{array}{l}\text { DU1 } \\
\text { DU2 } \\
\text { DU3 } \\
\text { DU4 }\end{array}$ & & & $\begin{array}{l}.81 \\
.57 \\
.50 \\
.47\end{array}$ & & & \\
\hline $\begin{array}{l}\text { PU1 } \\
\text { PU3 } \\
\text { PU4 }\end{array}$ & & & & $\begin{array}{l}.48 \\
.60 \\
.72\end{array}$ & & \\
\hline $\begin{array}{l}\text { PCU1 } \\
\text { PCU2 } \\
\text { PCU3 }\end{array}$ & & & & & & $\begin{array}{l}.72 \\
.79 \\
.67\end{array}$ \\
\hline $\begin{array}{l}\text { CU1 } \\
\text { CU2 } \\
\text { CU3 } \\
\text { CU4 }\end{array}$ & & $\begin{array}{l}.58 \\
.63 \\
.74 \\
.51\end{array}$ & & & & \\
\hline $\begin{array}{l}\text { GU1 } \\
\text { GU2 } \\
\text { GU3 } \\
\text { GU4 }\end{array}$ & & $\begin{array}{l}.63 \\
.44 \\
.53 \\
.51\end{array}$ & & & & \\
\hline $\begin{array}{l}\text { CMU1 } \\
\text { CMU2 } \\
\text { CMU3 } \\
\text { CMU4 } \\
\text { CMU5 }\end{array}$ & $\begin{array}{l}.91 \\
.90 \\
.88 \\
.85 \\
.75 \\
\end{array}$ & & & & & \\
\hline Eigen value & 7.80 & 2.90 & 2.41 & 2.07 & 1.66 & 1.40 \\
\hline$\%$ of Variance & 26.9 & 10.0 & 8.31 & 7.13 & 5.72 & 4.82 \\
\hline $\begin{array}{l}\text { Cumulative \% } \\
\text { of variance }\end{array}$ & 26.9 & 36.9 & 45.2 & 52.3 & 58.1 & 62.9 \\
\hline
\end{tabular}

regard to normality, and it is especially good for ranking qualitative data (Hollander and Wolfe 1999) using a Likert-scale. Then rice industry sector aggregation was performed.

The normality of each sample group tested by the Shapiro-Wilk test should be explored, however, prior to run non-parametric analysis (Field 2009). In the rice miller data, the data for competitor behavior uncertainty appeared to be significantly non-normal. Meanwhile, in the rice exporter data, only the data for process, government policy, and climate uncertainty were significantly normal. The small sample size might be the main cause of this non-normality. Moreover, the homogeneity of variance assumption that was tested by the Levene's test at significant the level of 0.05 is not violated for all seven constructs.

The results of the Mann-Whitney test for two independent samples (see Table 6) show that perceived competitor behavior uncertainty by the two groups of Thai rice millers and rice exporters is significantly different at significance level 0.05 , while the perceived government policy uncertainty is significantly different at significance level 0.1 . Thus, the perceived supply, demand, process, planning and control, and climate uncertainty do not differ significantly along the partial rice supply chain in Thailand.

\section{Results}

The seven environmental uncertainties of the partial rice supply chain in Thailand were measured with descriptive Statistics as shown in Figure 2 and Table 6. The level of uncertainty values range from 3.75 to 5.65. The uncertainty factors can be divided into two groups. The first group is the high level of perceived uncertainty consisting of planning and control, competitor behavior, government policy, and climate uncertainty. The second group is the lower level of perceived uncertainty comprising supply, demand and process uncertainty. Government policy uncertainty is perceived at the highest level, while process uncertainty is perceived at the lowest level by both rice millers and exporters. Moreover, rice exporters perceived government policy and competitor behavior uncertainty to be significantly higher than did the rice millers. The Mann-Whitney test in Table 5 supports this finding. 
Table 5. Results of the Non-parametric test (the Mann-Whitney test) for two independent samples: rice millers and rice exporters

\begin{tabular}{|c|c|c|c|c|c|c|c|}
\hline \multicolumn{8}{|c|}{ Test Statistic ${ }^{2}$} \\
\hline & Supply & Demand & Process & $\begin{array}{l}\text { Planning } \\
\& \text { Control }\end{array}$ & Competitor & $\begin{array}{l}\text { Government } \\
\text { Policy }\end{array}$ & Climate \\
\hline Mann-Whitney U & 1040.00 & 932.00 & 884.00 & 1026.00 & 630.00 & 808.00 & 990.00 \\
\hline Wilcoxon W & 1040.00 & 932.00 & 884.00 & 1026.00 & 630.00 & 808.00 & 990.00 \\
\hline Z & 1040.00 & 932.00 & 884.00 & 1026.00 & 630.00 & 808.00 & 990.00 \\
\hline Asymp. Sig. (2-tailed) & 1040.00 & 932.00 & 884.00 & 1026.00 & 630.00 & 808.00 & 990.00 \\
\hline $\begin{array}{l}\text { a: Grouping variable }(1=r i \\
\text { b: Rejected significant lev }\end{array}$ & $\begin{array}{l}=\text { Rice exp } \\
\text { ejected sign }\end{array}$ & 0.10 & & & & & \\
\hline
\end{tabular}

\section{Discussion and Conclusion}

The measurement instrument of perceived environmental uncertainty in this research was developed from previous studies and was tested to assure adequate reliability and validity similar to the measurement instrument developed by Miller (1993) and Lewis \& Harvey (2001). The findings are clear evidence that high levels of planning and control, competitor behavior, government policy, and climate uncertainty are experienced in the Thai rice supply chain. In addition, the rice exporters perceive higher uncertainty than the rice millers. This is probably due to the fact that dealing with the international market and managing many tiers of exporters' suppliers, rice exporters face higher levels of uncertainty than those upstream in the supply chain.

Information technology is not implemented in the Thai rice industry and this lack of appropriate IT tools like Electronic Data Interchange (EDI) means that uncertainty factors cannot be dealt with effectively (Bensaou 1997). The high level of competitor behavior uncertainty indicates that the high competition on both domestic and international markets leads to high unpredictability of competitor behavior. An example of this is the intense competition among riceproducing countries leading Vietnam to introduce low price and low quality rice (Nielsen 2002). The high level of government policy uncertainty is likely to mean that government policies in developing countries are turbulent and unpredictable (Badri et al. 2000). That rice supply chain members perceive highly unpredictable climate uncertainty is obvious in the Thai rice industry. This supports the fact that climate is a vital factor having both direct and indirect effects on most agricultural and socio-economic systems especially in developing countries where the agricultural system is mostly dependent on rainfall, and there is a lack of technological adaptations (Darwin et al. 1995; Ogallo et al. 2000). In addition,

Table 6. Descriptive Statistics of seven uncertainty factors perceived by rice millers and exporters

\begin{tabular}{|l|l|r|r|c|}
\hline Factors & SC Member & N & Mean & Std. Deviation \\
\hline SU & Rice Millers & 98 & 4.2321 & 1.2731 \\
(No SU2) & Rice Exporters & 22 & 4.3030 & 1.3836 \\
& Total & 120 & 4.3194 & 1,2880 \\
\hline DU & Rice Millers & 98 & 4.3061 & 1.2674 \\
& Rice Exporters & 22 & 4.5682 & 1.1807 \\
& Total & 120 & 4.3194 & 1.2513 \\
\hline PU & Rice Millers & 98 & 3.8163 & 1.2880 \\
(No PU2) & Rice Exporters & 22 & 4.1515 & 0.9356 \\
& Total & 120 & 3.8778 & 1.2344 \\
\hline \multirow{2}{*}{ PCU } & Rice Millers & 98 & 4.9388 & 1.0802 \\
(No PCU4) & Rice Exporters & 22 & 4.9394 & 0.9630 \\
& Total & 120 & 4.9389 & 1.0558 \\
\hline CU & Rice Millers & 98 & 4.7347 & 1.1834 \\
& Rice Exporters & 22 & 5.5909 & 0.8815 \\
& Total & 120 & 4.8917 & 1.1787 \\
\hline \multirow{2}{*}{ GU } & Rice Millers & 98 & 5.0153 & 1.4399 \\
& Rice Exporters & 22 & 5.6364 & 0.9902 \\
& Total & 120 & 5.1292 & 1.3861 \\
\hline CMU & Rice Millers & 98 & 5.000 & 1.4884 \\
& Rice Exporters & 22 & 5.1818 & 1.6549 \\
& Total & 120 & 5.0333 & 1.5146 \\
\hline
\end{tabular}


Figure 2. Graphs showing the level of perceived environmental uncertainty along the partial Thai rice supply chain (rice millers and rice exporters)

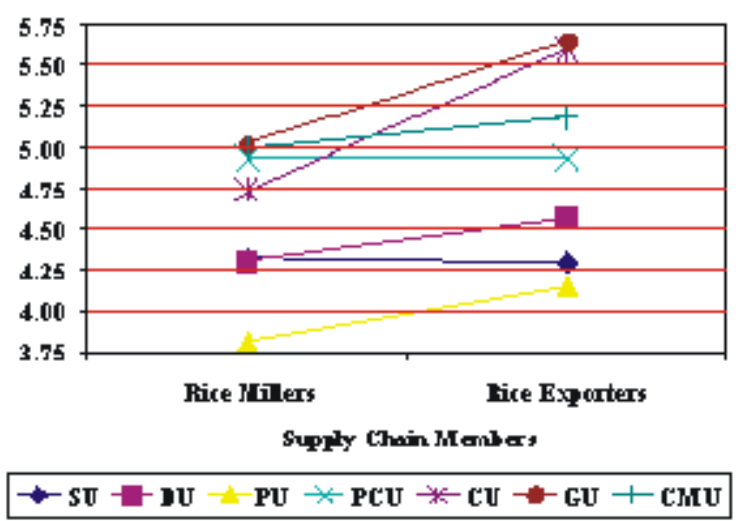

climate uncertainty is manifest at the organisation level all along the rice supply chain. On the other hand, these findings do not confirm the results of Li's
(2002) study showing that customer, supplier, competitor behavior, and technology uncertainty do not impact on any supply chains in the USA.

The implication for further research is needed on perceived environmental uncertainty in the Thai rice supply chain focusing on rice farmers who are rice producers in order to understand the uncertainty factors for the entire rice supply chain. In this study, data from farmers has been ignored because the population of rice farmers in Thailand is over 30 million people (IRRI 2002), making the distribution of questionnaires and the collection of data impractical. Furthermore, most of these farmers are uneducated. Face-to-face surveys would be needed in order to collect data from farmers for further study. The implication for managers is that they need to clearly understand the environmental uncertainty of the supply chain in order to maintain and improve the competition position by improving strategic decision-making under higher levels of uncertainty (Lewis and Harvey 2001).

\section{Appendix A}

Table A1: The measurement items of uncertain factors in Thai rice supply chain.

\begin{tabular}{|c|c|c|c|}
\hline Uncertain Factors & $\begin{array}{l}\text { Aspects of } \\
\text { measurement }\end{array}$ & The question in the questionnaire & References \\
\hline \multirow[t]{3}{*}{ Supply } & Quantity & SU1: Rice quantity from rice producers is unpredictable & \multirow{3}{*}{$\begin{array}{l}\text { (van der Vorst 2000; } \\
\text { Li 2002; Paulraj and } \\
\text { Chen 2007) }\end{array}$} \\
\hline & Quality & $\begin{array}{l}\text { SU2: The properties of rice from rice producer can vary greatly with in the same batch } \\
\text { (a) } \\
\text { SU3: Rice quality from rice producers is unpredictable }\end{array}$ & \\
\hline & Time & SU4: Rice producers' delivery time is unpredictable & \\
\hline \multirow[t]{3}{*}{ Demand } & Quantity & DU1: The volume of customer demand is difficult to predict & \multirow{3}{*}{$\begin{array}{l}\text { (Li 2002; Paulraj } \\
\text { and Chen 2007) }\end{array}$} \\
\hline & Quality & DU2: Customers' rice preference changes over the year & \\
\hline & Time & $\begin{array}{l}\text { DU3: The lead time }{ }^{1} \text { of customer order is unpredictable } \\
\text { DU4: Master production schedule has a high percentage of variation in demand }\end{array}$ & \\
\hline \multirow[t]{3}{*}{ Process } & Quantity & $\begin{array}{l}\text { PU1: Yield of rice processing (e.g. milling, packing) can vary } \\
\text { PU2: The amount of rice product is enough for distribution as required (a) }\end{array}$ & \multirow[t]{3}{*}{ (van der Vorst 2000) } \\
\hline & Quality & PU3: The quality of rice after processed (e.g. milled, storied ) can be changed & \\
\hline & Time & PU4: The throughput time of rice processing can vary & \\
\hline \multirow[t]{3}{*}{$\begin{array}{l}\text { Planning and } \\
\text { Control }\end{array}$} & Quantity & $\begin{array}{l}\text { PCU1: Information of stock level of rice and rice production capacity is complete at } \\
\text { this moment }\end{array}$ & \multirow[t]{3}{*}{ (van der Vorst 2000) } \\
\hline & Quality & PCU2: Information of stock level of rice and rice production capacity is accurate & \\
\hline & Time & $\begin{array}{l}\text { PCU3: Information of stock level of rice and rice production capacity is timely } \\
\text { PCU4: Information concerning changes of customer orders can not be distributed on } \\
\text { time (a) }\end{array}$ & \\
\hline
\end{tabular}




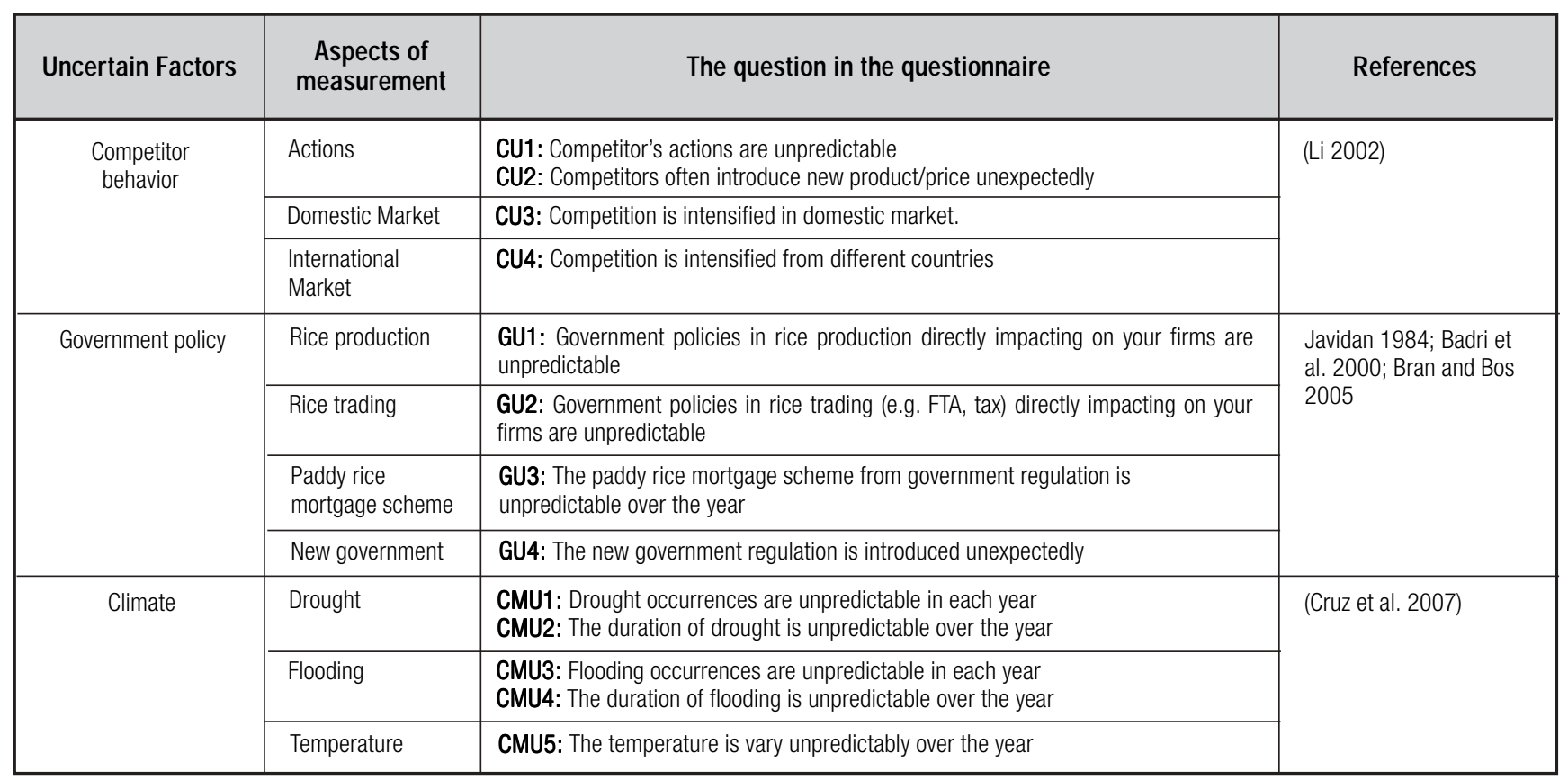

${ }^{1}$ lead time: duration time from costumers placing their order to their requested product shipment. (a): items deleted

\section{References}

Ahmed, Z. U., Mohamad, O., Johnson, J., P. and Meng, L. Y. (2002). Export promotion programs of Malaysian firms: An international marketing perspective. Journal of Business Research 55 (10): 831-843

Badri, M. A., Davis, D. and Davis, D. (2000). Operations strategy, environmental uncertainty and performance: a path analytic model of industries in developing countries. Omega 28 (2): 155-173.

Bensaou, M. (1997). Interorganizational cooperation: The role of information technology an empirical comparison of US and Japanese supplier relations. Information Systems Research 8 (2): 107-124.

Bhatnagar, R. and Sohal, A. S. (2005). Supply chain competitiveness: measuring the impact of location factors, uncertainty and manufacturing practices. Technovation 25 (5): $443-456$

Bolton, J. M. and Dwyer, K. (2003). Chapter 6.1: Achieving supply chain alignment through behavior change. Gower handbook of supply chain management. J. L. Gattorna. Burlington, USA, Gower.

Bourgeois, L. J., III (1978). Strategy making, Environment, and economic performance: A conceptual and empirical exploration. Washington, United States, University of Washington. Ph.D: pp 226.

Bourgeois, L. J., III (1980). Strategy and Environment: A Conceptual Integration. Academy of Management. The Academy of Management Review 5 (1): 25-39.
Boyle, E., Humphreys, P. and McIvor, R. (2008). Reducing supply chain environmental uncertainty through eintermediation: An organisation theory perspective. International Journal of Production Economics 114 (1): 347362.

Bran, J. v. and Bos, M. S. (2005). The changing economics and politics of rice: implications for food security, globalization, and environmental sustainability. Rice is life: scientific perpectives for the 21st century. $\mathrm{K}$. Toriyama, K. Heong and B. Hardy.

Bryman, A. (2003). Business research methods. Oxford, Oxford University Press.

Calpe, C. (2004). International trade in rice: recent developments and prospects. Rice is life: scientific perspectives for the 21st century, Proceedings of the World Rice Research Conference held in Tokyo and Tsukuba, Japan, 4-7 November 2004, International Rice Research Institute.

Childerhouse, P., Disney, S. and Towill, D. (2008). On the impact of order volatility in the European automotive sector. International Journal of Production Economics 114 (1): 2-13.

Childerhouse, P. and Towill, D. R. (2004). Reducing uncertainty in European supply chains. Journal of Manufacturing Technology Management 15 (7): 585-598.

Cramer, D. (2003). Advanced quantitative data analysis. Maidenhead, England ; Philadelpha, PA, Open University Press.

Cruz, R. V., Harasawa, H., Lal, M. and Wu, S. (2007). Chapter 10 Asia: Climate Change 2007: Impacts, Adaptation and 
Vulnerability IPCC Fourth Assessment Report: Working Group II Report Cambridge, UK, Cambridge University Press: 469-506.

Darwin, R., Tsigas, M., Lewandrowski, J. and Raneses, A. (1995). World Agriculture and Climate Change: Economic Adaptations, Agricultural Economic Report Number 703, United States Department of Agriculture.

David, C. C. (1992). Chapter 1: The World Rice Economy: Challenges Ahead. Philippines, The International Rice Research Institute (IRRI).

Davis, T. (1993). Effective Supply Chain Management. Sloan Management Review 34 (4): 35-46.

Dill, W. R. (1958). Environment as an influence on managerial autonomy. Administrative Science Quarterly 2: $409-443$.

Downey, H. K., Hellriegel, D. and et al. (1975). Environmental Uncertainty - The Construct and Its Application. Administrative Science Quarterly 20 (4): 613629.

Duncan, R. B. (1972). Characteristics of Organizational Environments and Perceived Environmental Uncertainties. Administrative Science Quarterly 17 (3): 313-327.

FAO. (2009a, June 2009). "Food Outlook: Global Market Analysis - June 2009." from http://www.fao.org/ docrep/011/ai482e/ai482e05.htm.

FAO. (2009b, June 2009). "Rice Market Monitor." from h t t p : //w w w.f a o.org /e s /ESC/en /1 5 /7 0/ highlight_71.html.

FAOSTAT Database (2008). World Rice Statistics. Rome, FAO Statistics Division

FAPRI. (2008). “U.S. and World Agricultural Outlook 2008." from http://www.fapri.iastate.edu/outlook2008/

Fawcett, S. E. (2007). Supply chain management : from vision to implementation. Harlow, Prentice Hall.

Field, A. P. (2005). Discovering Statistics Using SPSS (Introducing Statistical Methods series), 2nd. London, Sage.

Field, A. P. (2009). Discovering statistics using SPSS, 3rd. London, SAGE.

Flynn, B. B., Sakakibara, S., Schroeder, R. G., Bates, K. A. and Flynn, E. J. (1990). Empirical Research Methods in Operations Management. Journal of Operations Management 9 (2): 250-284.

Frazelle, E. H. (2002). Supply Chain Strategy: The Logistics of Supply Chain Management. New York, McGrew Hill.

Gorry, G. A. and Morton, M. S. S. (1989). A Framework For Management Information Systems. Sloan Management Review 30 (3): 49-61.

Gummert, M. and Rickman, J. F. (2006). "Rice: Drying." from http://www.knowledgebank.irri.org/Drying/ default.htm.
Hair, J. F., Anderson, R. E., Tatham, R. L. and Black, W. C. (1995). Multivariate data analysis : with readings, 4 th. Englewood Cliffs, New Jersey, Prentice-Hall.

Han, J. K., Kim, N. and Srivastava, R. K. (1998). Market orientation and organizational performance: Is innovation a missing link? Journal of Marketing 62 (4): 30.

Heiens, R. A. (2000). Market Orientation: Toward an Integrated Framework. Academy of Marketing Science Review 2000

Herdt, W. R. (1992). Chapter 2: Research Priorities for Rice Biotechnology. New York, USA, The Rockefeller Foundation.

Hollander, M. and Wolfe, A. D. (1999). Nonparametric statistical methods, 2nd. New York.

Hsiao, H. I., van der Vorst, J. G. A. J. and Omta, S. W. F. (2006). Logistics outsourcing in food supply chain networks: Theory and practices. International agri-food chains and networks : management and organization. J. Bijman, S. W. F. Omta, J. H. Trienekens, J. H. M. Wijnands and E. F. M. Wubben. Netherlands, Wageningen Academic Publishers: 135-150.

Hsiao, J.-M. M. (2006). The Impact of Retailer-Supplier Cooperation and Decision-Making Uncertainty on Supply Chain Performance. Institute of Transport and Logistics Studies, Faculty of Economics and Business, The University of Sydney. Doctor of Philosophy pp 287.

International Rice Research Institute (2007). Rice around the world. Rice Almanac, www.irri.org/science/cnyinfo/ pdf/Thailand.pdf.

IPCC. (2001). "http:/www.onep.go.th/cdm/en/cmc.html."

IRRI (1991). World Rice Statistics. Philippines, The International Rice Research Institute (IRRI).

IRRI. (2002). "Rice around the world." Rice Almanac, from www.irri.org/science/cnyinfo/pdf/Thailand.pdf.

Javidan, M. (1984). The Impact of Environmental Uncertainty on Long-range Planning Practices of the U.S. Savings and Loan Industry. Strategic Management Journal 5 (4): 381-392.

Jayne, T. S. (1993). Sources and Effects of Instability in the World Rice Market. MSU International Development Papers. C. Liedholm and M. T. Weber. Michigan, USA, Department of Agricultural Economics, Department of Economics, MICHIGAN STATE UNIVERSITY.

Kaiser, H. F. (1974). An index of factorial simplicity. Psychometrika 39: 31-36.

Krasachat, W. (2004). Technical Efficiencies of Rice Farms in Thailand: A Non-Parametric Approach. Journal of American Academy of Business, Cambridge 4 (1/2): 64-69.

Lewis, G. J. and Harvey, B. (2001). Perceived environmental uncertainty: The extension of Miller's scale to the natural environment. The Journal of Management Studies 38 (2): 201-233. 
Li, S. (2002). An Integrated Model for Supply Chain Management Practice, Performance and Competitive Advantage. Manufacturing Management, The University of Toledo. Doctor of Philosophy: pp 266.

Marcus, A. A. (1981). Policy Uncertainty and Technological Innovation. Academy of Management. The Academy of Management Review 6 (3): 443-448.

Matsuda, T. (1990). Intensification of land use and rice farming. Thai Rice Farming in Transition. A. Fujimoto, K. Adulavidhaya and T. Matsuda. Tokyo, Japan, World Planning Co.,LTD.

Matthews, R. and Wassmann, R. (2003). Modelling the impacts of climate change and methane emission reductions on rice production: a review. European Journal of Agronomy 19 (4): 573-598.

Meenaphant, S. (1981). An Economic Analysis of Thailand's Rice Trade. Houston, Texas, Rice University. Doctor of Philosophy: pp 231.

Mendoza, M. S. and Farris, P. L. (1992). The impact of changes in government policies on economic performance (the ARCH model). Journal of Policy Modeling 14 (2): 209-220.

Mentzer, J. T., Min, S. and Zacharia, Z. G. (2000). The nature of interfirm partnering in supply chain management. Journal of Retailing 76 (4): 549-568.

Miller, K. D. (1993). Industry and country effects on managers' perceptions of environmental uncertainties. Journal of International Business Studies 24 (4): 693-714.

Milliken, F. J. (1987). Three Types of Perceived Uncertainty About the Environment: State, Effect, and Response Uncertainty. Academy of Management. The Academy of Management Review 12 (1): 133-143.

Min, S. and Mentzer, J. T. (2000). The role of marketing in supply chain management. International Journal of Physical Distribution E Logistics Management 30 (9): 765785.

Nielsen, C. P. (2002). Vietnam in the International Rice Market: A Review and Evaluation of Domestic and Foreign Rice Policies. Denmark, Institute of Food and Resource Economics (FOI),Faculty of Life Sciences, University of Copenhagen.

Nunnally, J. C. (1967). Psychometric theory. New York, McGraw-Hill.

Office of Agricultural Economics. (2007). "Chapter 1: Overview of Agricultural economic in Thailand." The Indicator of agricultural economic in Thailand (in Thai), from http://www.oae.go.th/indicator/indicator50/.

Office of Agricultural Economics. (2009). "The statistics of export and import rice." from http://www.oae.go.th/ oae_report/export_import/export_result.php.

Ogallo, L. A., Boulahya, M. S. and Keane, T. (2000). Applications of seasonal to interannual climate prediction in agricultural planning and operations. Agricultural and Forest Meteorology 103 (1-2): 159-166.
Paulraj, A. and Chen, I. J. (2007). Environmental Uncertainty and Strategic Supply Management: A Resource Dependence Perspective and Performance Implications. Journal of Supply Chain Management 43 (3): 29-42.

Porter, M. E. (1980). Competitive strategy: techniques for analyzing industries and competitors. New York, The Free Press.

Roumasset, J. and Setboonsarng, S. (1988). Second-best agricultural policy : Getting the price of Thai rice right. Journal of Development Economics 28 (3): 323-340.

Sheskin, D. (1997). Handbook of parametric and nonparametric statistical procedures. Boca Raton, Fla., CRC Press.

Slater, S. F. and Narver, J. C. (1994). Market orientation, customer value, and superior performance. Business Horizons 37 (2): 22-28.

Sriswasdilek, J. (1990). Irrigation and water management for rice production in Suphan Buri. Thai Rice Farming in Transition. A. Fujimoto, K. Adulavidhaya and T. Matsuda. Tokyo, Japan, World Planning Co.,LTD.

Sukin, K. (2004). Climate change study: Jasmine rice yields at risk. The Nation. Bangkok.

Taylor, D. H. and Fearne, A. (2006). Towards a framework for improvement in the management of demand in agri-food supply chains. Supply Chain Management 11 (5): 379-384.

Thai Rice Foundation under Royal Patronage. (2006a). "Rice Farming." from www.thairice.org/eng/aboutRice/ abount_rice3.htm.

Thai Rice Foundation under Royal Patronage. (2006b). "Rice Trade." from www.thairice.org/eng/aboutRice/ rice_trade.htm.

The Office of Natural Resources and Environmental Policy and Planning. (2008). "CLIMATE CHANGE: Impact in Thailand." 2009, from http://www2.onep.go.th/CDM/ en/index.html.

The Thai National Rice Policy Committee (2009). Summary of the National Rice Policy Conference, No. 6/2552. In Thai. Bangkok, The Department of Internal Trade, The Ministry of Commerce, Thailand.

van der Vorst, J. G. A. J. (2000). Effective food supply chains : generating, modelling and evaluating supply chain scenarios, Wageningen University. Doctor of Philosophy: pp 305.

van der Vorst, J. G. A. J. and Beulens, A. J. M. (2002). Identifying sources of uncertainty to generate supply chain redesign strategies. International Journal of Physical Distribution \& Logistics Management 32 (6): 409-430.

van Donk, D. P. and van der Vaart, T. (2005). A case of shared resources, uncertainty and supply chain integration in the process industry. International Journal of Production Economics 96 (1): 97-108.

Wijnands, J. H. M. and Ondersteijn, C. J. M. (2006). Chapter 1 Quantify the agr-food supply chain: overview and new research directions. Quantifying the agri-food supply chain. C. J. M. Ondersteijn, J. H. M. Wijnands, R. B. M. Huirne and O. van Kooten. Dordrecht, Springer: 3-12. 
Wilding, R. (1998). The supply chain complexity triangle: Uncertainty generation in the supply chain. International Journal of Physical Distribution $\mathcal{E}$ Logistics Management 28 (8): 599-613.

World Bank (2009). Thailand Economic Monitor: April-June 2009. F. G. Sander, K. Bhaopichitr, V. Sirimaneetham, N. Triratanasirikul and R. Anantavrasilpa. Bangkok, Thailand.
Yao, S. (1997). Rice production in Thailand seen through a policy analysis matrix. Food Policy 22 (6): 547-560.

Yao, S. (1999). Efficiency impacts of Government policy on agricultural production in the presence of externalities. Journal of Environmental Management 55 (1): 57-67.

Yoshida, S. (1981). Fundamentals of Rice Crop Science. Philippines, The International Rice Research Institute (IRRI).

Phatcharee Toghaw Thongrattana is a PhD candidate from the Sydney Business School, University of Wollongong, Australia. She is a lecturer with the Department of Industrial Engineering, Faculty of Engineering, Kasetsart University in Thailand, where she teaches applied probability and statistics, manufacturing and industrial engineering. She holds a Master of Engineering in Industrial Engineering from Kasetsart University and a Bachelor of Engineering from Suranaree University of Technology, also in Thailand. Her current research interest is in agricultural supply chain management.

Dr. Nelson Perera is Associate Professor in the Sydney Business School, University of Wollongong, Australia. He earned a Bachelor of Science (first class) degree from the University of Sri Lanka, a Master's degree (honours) in Commerce from the University of Wollongong and a PhD in Economics from La Trobe University. Since joining the University of Wollongong, Nelson has taught statistics, forecasting, econometrics, management science, operational research and quantitative research methods for marketing. His research interests are mainly in the fields of monetary policy, applied econometrics and application of statistics to business area. 